\title{
CLDN6 Gene
}

National Cancer Institute

\section{Source}

National Cancer Institute. CLDN6 Gene. NCI Thesaurus. Code C117143.

This gene is involved in tight junction formation. 